\title{
Fumigant Potential of seed kernel oil of Putranjiva roxburghii Wall against storage pests of seeds of Dalbergia sissoo Roxb
}

\author{
Dr. Narendra Kumar \\ Bacteriology and Natural Pesticide Laboratory,Department of Botany,DDU Gorakhpur University, Gorakhpur- \\ 273009,Uttar Pradesh,India
}

\begin{abstract}
Seed samples were collected from 25 places of north eastern U.P from luxuriantly growing and healthy D.sissoo Roxb plants and stored at room temperature for 6 months.Mycofloral analysis through blotter method revealed the presence of 15 fungal species and agar plate method using czapeks dox agar medium showed the presence of 12 fungal species.During observation one insect-Bruchus pisorum was found to be present in all collected samples.The pathogenicity test put A.niger and Fusarium solani and insect-Bruchus pisorum highly potent and caused high degree of inhibition in germination and also caused high degree of mortality.Volatile constituents extracted in the form of essential oils from 32 plant species were evaluated against the dominant fungi Aspergillus niger and Fusarium solani as well as against insect-Bruchus bisporum.The seed kernel oil of Putranjiva exhibited the greatest toxicity.The oil was found to be fungicidal and thermostable at its minimum inhibitory concentration(MIC)400ppm.The oil was characterized by the determination of its various physicochemical properties.

The oil protected the sissoo seeds completely for 6 months at $0.25 \mathrm{ml}$ (1000ppm)and $0.38 \mathrm{ml}(1500 \mathrm{ppm})$ in container of $250 \mathrm{ml}$ capacity holding $200 \mathrm{~g}$ seeds.It did not exhibit any adverse effect on seed germination,seedling growth and general health and morphology of plants.Thus the seed kernel oil of Putranjiva showed potential as a preservative for sissoo seeds against spoilage by fungi and insects during storage.

Key Words; Storage pest of shisham, culture filterate, mortality, synthetic fumigant
\end{abstract}

\section{Introduction}

Sissoo or Shisham(Dalbergia sissoo Roxb), a deciduous tree of family Papillionaceae, is an important plant of great economic value . D. sissoo is best known internationally as a premier timber species of the rosewood genus. However, it is also an important fuel wood, shade and shelter. With its multiple products and tolerant of light frosts and long dry seasons, this species deserves greater consideration for tree farming, reforestation and agro-forestry applications.

D. sissoo is a multipurpose tree and produces nitrogen-rich fodder and green manures, high quality fuel-wood and charcoal, strong and durable poles, and beautiful dark brown wood for furniture and paneling. It is also used in agroforestry system to protect soil, improve crop production (due to nitrogen fixation) and provide long-term financial security. These characteristics make D. sissoo a popular species for afforestation, industrial plantations and farm forestry planting. It is a valuable resource for national forestry program, commercial enterprises and private farmers.

Rajendran(2002) highlighted that stored products of agricultural and animal origin are attacked by more than 600 species of beetle pests, 70species of moths and about 355 species of mites causing quantitative and qualitative losses .Taylor(1989)and Collins et al(2002) reported that fumigation plays a major role in insect pest elimination in stored products. Currently,phosphine and methyl bromide are the two common fumigants used for stored-product protection worldover.Insect resistance to phosphine is a global issue now and control failures have been reported in field situations in some countries. Methyl bromide, a broad-spectrum fumigant,has been declared an ozone-depleting substance and therefore, is being phased out completely. Inview of the problems with the current fumigants, there is a global interest in alternative strategies including development of chemical substitutes, exploitation of controlled atmospheres and integration of physical methods (MBTOC,2002). The interest has been shown in plant products, i.e., essential oils for fumigant action since it is believed that natural compounds from plant sources may have the advantage over conventional fumigants in terms of low mammalian toxicity, rapid degradation and local availability. The range of fungi on sissoo seed during storage are large.Richardson(1990)reported several species of Aspergillus, Penicillium,Rhizopus, Alternaria,Fusarium,Chaetomium,Drechslera and Curvularia from forest tree seeds.Mustafa et al(2004) isolated Rhizoctonia solani,Fusarium solani,F.oxysporum,F.moniliforme,Aspergillus niger,Alternaria alternata and Helminthosporium spp.,as seed borne fungi from seed samples of shisham.

In north eastern U.P no systematic work has been done on post harvest storage pest of sissoo seed and their impact on seed germination and mortality in north eastern U.P. and less attention has been focused on plant 
products showing fumigant action against storage pest of sissoo. In present investigation storage pest of freshly collected and stored seeds of sissoo were studied. The effect of culture filterates of seed borne fungi and insectBruchus pisorum on seed germination and mortality were compared.Essential oils were isolated from 32 plants and evaluated against the dominant fungi and insect species in the search for a renewable,natural protectants for sissoo seeds.Effectiveness of the most active oil was compared with that of synthetic fumigant aluminium phosphide and ethylene dibromide in terms of its effect on the mycoflora,seed germination,seedling growth and general health and morphology of sissoo after 6 months of storage. The comparative in-vivo efficacy of most potent oil and aluminium phosphide and ethylene dibromide at 1000ppm and 1500ppm were compared.

\section{Seed collection}

\section{Materials and Methods}

Ripe fruits were harvested from December to March(2008-10). The fruits were collected from the tree by climbing and by shaking the fruits onto a tarpaulin on the ground. Pods were dried in the sun for 3 to 4 days. Well dried and moisture protected pods were kept for 3 months storage in a storage cabinet.

Twenty five places were visited for collection of pods containing seed samples in five districts of north eastern Uttar Pradesh.

Collection Place

Basti district-Ganeshpur,Kalwari,Makhauda,Chhawni Bazar,Walterganj

in Santkabir nagar district-Baghnagar,Mehdaul,Matiuli,Alinagar,Gagargarh,

in Siddhartha nagar district-Bansi,Itwa,Chandapar,Chilia,Birdpur

inGorakhpur district-Brhalganj,Golabazar,Kauriram,Kusmi,Pali

in Maharajganj district-Nautanwa,Sanduriya,Khucha,Paniyara,Nichlaul

\section{Storage pest analysis of collected and stored seeds}

The seeds were analysed for their mycoflora through agar plate(Muskett,1948) using czapek dox agar medium and standard blotter(De Tempe,1953)techniques.In agar plate technique,100seeds were equidistantly spread out on czapeks dox agar medium in separate petri plates,each containing 5 seeds.In blotter test,the seeds were similarily plated on three layered moistened blotter pads in sterilized petriplates. The assay plates were then incubated at $28 \pm 2{ }^{\circ} \mathrm{C}$ and observed daily upto 7 days for appearance of fungal isolates.Pure cultures of each isolates were maintained on a czepks dox agar slants and identified.

In order to detect the internal seed mycoflora,the seeds were first surface sterilized with $0.1 \%$ sodium hpochlorite for five minutes washed with sterilized distilled water and then subjected to agar plate and standard blotter techniques for isolation of the fungi.Excess water was removed from the seed using folds of sterilized blotters.Drying the seeds in sterilized blotters before plating on agar plates helped to reduce bacterial and actinomycete contamination to a great extant.This enables superficial inoculums to be separated from the one which is deep seated(Neergaard,1977). The insects were examined by hand lens.

Fungal identifications were confirmed on the basis of colony characters and by examining the slide preparation under microscope.Keys and description given by Raper and Thom(1949),Gilman(1967), Raper and Fennell(1965),Booth(1971) and Ellis(1971,76) were followed.

\section{Effect of storage pest on germination and mortality on sissoo}

The fungi isolated from seeds were tested for their pathogenic nature by studying the effects of culture filterates on seed germination and mortality.The fungal species were cultured in czapeks solutions for 15 days at28 $\pm 2{ }^{\circ} \mathrm{C}$ in stationary conditions. The cultures were filtered through whatman no-1 filter paper and the filterates were used to assay the toxin produced by assessing the percentage inhibition of seed germination and mortality of sissoo.

Freshly harvested surface sterilized( $0.1 \%$ sodium hypochlorite solution) and washed (sterilized water) seeds were soaked separately for overnight in $100 \mathrm{ml}$ of each culture filterate of corresponding sissoo seed fungi in four replication of 25 seeds each. 25 treated seeds were placed in sterilized petridish containing three layers of moist blotters. The number of seeds germinated after 5 days interval for upto 20 days was observed and the final percentage of germination and mortality was recorded till there was no further germination. The controls were maintained by sowing surface sterilized seeds in sterilized blotters.

The deterioration caused by insect was evaluated following Kumar and Tripathi(2004).

\section{Isolation of essential oils from higher plants and evaluation of their toxicity against test fungi and insect}

The plant parts of 32 higher plants collected separately from Gorakhpur locality were surface sterilized by dipping in $70 \%$ ethanol and then washed repeatedly with sterilized double distilled water.The surface sterilized leaves were macerated and hydrodistilled for isolation of volatile constituents separately for 6 hour in clevengers 
apparatus.After hydrodistillation immiscible oil was separated and dehydrated over anhydrous sodium sulphate separately to remove traces of moisture.

The toxicity of oil was assessed by using the inverted petri plate technique of Bocher(1938). The fungitoxicity of essential oils was measured following Dixit et al(1978) and recorded in terms of per cent inhibition of mycelial growth.

The repellent activity of the oils against insect was studied following the method of Tripathi and Kumar(2007).Different amounts $(0.005,0.01$ and $0.02 \mathrm{ml})$ of the oil from each plant were applied separately into test sponge pieces and the test pieces were placed in one of the arms of Y tube olfactometer.Water soaked sponge pieces were placed in the other arms as controls. Twenty newly emerged adults of Bruchus pisorum obtained from a culture maintained in the laboratory were introduced into the basal arm of the Y olfactometer in 4 batches at interval of $5 \mathrm{~min}$ to avoid mutual interference, if any.To compensate for possible minor asymmetry in the construction of olfactometer(made locally of corning tube) or in the experimental condition, the position of the test material(oil) and control(water) in the arms were alternated.The number of individuals in each arm were counted at the end of the test(after $30 \mathrm{~min}$ ). The experiment was repeated five times for each set of tests.

\section{Physico-chemical properties of Putranjiva seed kernel oil}

The oil was characterized by determination of its specific gravity,specific rotation,refractive index, acid value,saponification number,ester number,phenolic content and solubility following the methods of Langenau(1948).

\section{Fungitoxic properties of Putranjiva seed kernel oil}

The MIC of most active oil was determined by poisoned food technique of Grover and Moore(1962).Different concentration of the oil ranging from 200 to 600ppm were prepared by dissolving requsite amount of oil in $0.5 \mathrm{ml}$ acetone and then mixing with $9.5 \mathrm{mlczapeks}$ dox agar medium eperately.In control sets the petriplates having acetone and medium without oil were used.Fungal discs $(5 \mathrm{~mm}$ diam) abtained from periphery of seven d old culture of each of test fungi were aseptically inoculated in each of the treatment and control sets.All these sets were incubated at 28+-2C for 6 days.Diameters of fungal colony of treatment/control sets were measured in mutually perpendicular directions on the $7^{\text {th }} \mathrm{d}$ and the average was used to calculate the percent inhibition of mycelia growth of test fungi separately.The oil treated discs of the fungi showing complete inhibition of their mycelia growth upto $7 \mathrm{~d}$ were washed with sterile water and placed again on fresh solidified medium to observe the revival of mycelia growth. The fungitoxic spectrum of the oil was studied against various fungi isolated from root samples.In addition effect of temperature ,autoclaving and storage on the fungitoxicity of oil was determined following Pandey et al(1982).Each experiment was repeated twice and contained 5 replicates.

\section{Comparision of treatment with Putranjiva seed kernel oil and fumigation with synthetic fumigant- aluminium phosphide and ethylene dibromide}

Fresh dried sissoo seeds were locally collected from Gorakhpur district of eastern Uttar Pradesh in presterilized polyethylene bags.Aliquots of $0.25 \mathrm{ml}(1000 \mathrm{ppm})$ and $0.38 \mathrm{ml}(1500 \mathrm{ppm})$ of oil and ethylene dibromide were used separately with $200 \mathrm{~g}$ of freshly dried sissoo seeds in presterilized gunny bags of $250 \mathrm{ml}$ capacity.Likewise samples of sissoo to be treated with oil or ethylene dibromide were stored separately in metal containers(tins) of $250 \mathrm{ml}$ capacity.

Sterile cotton swabs $(0.25 \mathrm{~g})$, soaked with doses of oil or ethylene dibromide and wrapped in sterilized muslin cloth $(0.50 \mathrm{~g})$ were placed at the bottom of each container of sissoo.Similarily, $200 \mathrm{~g}$ samples of sissoo were treated with phosphine from a $0.25(1000 \mathrm{ppm})$ or $0.38 \mathrm{~g}(1500 \mathrm{ppm})$ of tablet $(80$ and $120 \mathrm{mg}$ equivalent phosphine) in $250 \mathrm{ml}$ containers and were stored in a cabinet in the Laboratory at room temperature for 6 months.Each set contained 5 replicates.Mycoflora associated with sissoo were then isolated by the agar plate technique of Muskett(1948) and the standard blotter technique of Tempe(1953).The insects were examined by hand lens.

After 6 months storage,germination tests were carried out.One hundred seeds were selected randomly from each test lot and aseptically placed in presterilized petridishes containing three layers of moistened blotting paper.The blotting papers were moistened with sterilized water at 2 day intervals. All sets were incubated at $28 \pm$ $2{ }^{\circ} \mathrm{C}$ in a dark chamber and germination was assessed from $10^{\text {th }}$ to the $25^{\text {th }}$ day.

The germinated seeds were allowed to grow for 25 days and radicle and plumule lengths were recorded on the $15^{\text {th }}, 20^{\text {th }}$ and $25^{\text {th }}$ day.

One hundred sissoo seed from each treatment and control sets were sown in $15 \times 20 \mathrm{~cm}$ earthen pots $(5$ seeds in each pot) containing garden soil. The pots were irrigated at intervals of 4 days. After 45 days, the plants were observed for general health and morphology. 


\section{Storage pests}

\section{Results}

The most frequent genera were Aspergillus represented by seven species followed by Fusarium(represented by three species).Highest percentage incidence were F.moniliforme and A.flavus(7.4 each)followed by Fusarium oxysporum(6.3) F.solani(5.4) and Penicillium glabrum(4.1).Other species of fungi like Alternaria alternata,Aspergillus candidus,A.phoenicus,A.tamarii,A.terreus,A.sydowi,Rhizopus nigricans,Trichothecium roseum,Trichoderma viride occurred less frequently. Seven fungal species of three genera were detected from surface sterilized seeds using moist blotter method.The most dominant genera were Aspergillus(represented by three species).Highest percentage incidence was of A.flavus(3.9) followed by A.niger and F.solani(2.5 each).Other forms like Alternaria alternata,Aspergillus sydowi,F.moniliforme and F.oxysporum were infrequent(Table1).

Twelb fungal species belonging to six genera were detected from unsterilized seeds plated over CDA medium. The most dominant genera were Aspergillus(represented by five species)followed by Fusarium(three species) and Penicillium glabrum.Highest percentage incidence was of A.flavus(19.9) followed by A.niger(14.1),Penicillium glabrum(11.2)F.oxysporum(6.3) and A.sydowi(5.0).Other fungi like Alternaria alternata,Aspergillus candidus,A.tamarii,F.moniliforme,F.solani,Trichoderma viride,Trichithecium roseum were less common. Five fungal species of two genera were isolated from surface sterilized seeds using CDA medium.The fungi recorded to be internally seed borne were A.flavus,A.niger,A.sydowi,F.oxysporum and F.solani(Table 1).In present investigation it was observed that in agar plate method fast growing fungi suppressed the development of other fungi making their detection difficult.Slow growing forms like Penicillium,Trichothecium and Trichoderma were better isolated in blotter method as compared to agar method.The blotter method seems to be superior to agar plate method.

During insect analysis only one insect-Bruchus pisorum(Linnaeus) was found to be present in all 25 collected samples which belongs to order Coleoptra and family-chrysomelidae.

\section{Description of insect}

The adults were 6 to7mm long,globular in shape with long legs. Elytra do not reach the end of the abdomen, leaving the last terga exposed.Last abdominal terga is covered with black and white setae and the inner ridge of the ventral margin of the hind femur has a single spine.Larvae were white and grub-like, having reduced legs

\section{Insects Damage symptoms}

Damage distinctive.Both adult and larvae fed on the inside of seeds.Feeding caused tiny, dot-like entrance holes. The feeding also caused larger, round exit holes with a diameter of $2.0 \mathrm{~mm}$ and excavated seed.Large populations reducd stored sissoo seed to little more than dust.

\section{Storage pest deterioration of sissoo seed}

The metabolites of most of the test fungi showed inhibitory effects on germination.The rating of fungi on the basis of inhibitory effects on germination put A.niger as highly potent.The other fungi in order of potentials for inhibiting seed germination were F.solani,A,tamari,F.moniliforme,A.phoenicus,A.flavus,F.oxysporum,Alternaria alternata,Aspergillus candidus,Penicillium glabrum,Rhizopus nigricans,Trichothecium roseum. The metabolite of A.sydowi and Trichoderma viride showed promotive effect on the germination of seeds of D.sissoo as compared to control.The insect-Bruchus pisorum caused 20\%germination and $80 \%$ mortality.It is evident from table 2 , that A.niger and F.solani and insect-Bruchus pisorum caused high degree of mortality and reduction in germination.

\section{Evaluation of essential oils against test organisms}

The essential oil of seed kernel of Putranjiva roxburghii Wall exhibited absolute toxicity at 500ppm inhibiting mycelial growth of both test fungi completely,while other oils at these concentrations showed moderate,lower level of fungitoxicity(Table 3). The seed kernel oil showed 100\% repellency against test insect Bruchus pisorum with a dose of $0.02 \mathrm{ml}$.Other oils at this concentration showed moderate or lower level of repellency(Table4).

The physicochemical properties of the seed kernel oil from Putranjiva roxburghii are recorded in Table5.

\section{Fungitoxic properties of Putranjiva seed kernel oil}

The MIC of the oil was found to be 400ppm against both the test fungi.The oil exhibited fungicidal nature at hyper MIC against both the test fungi(Table 6)while it was fungicidal in nature at 500ppm. The seed kernel oil of Putranjiva completely inhibited the mycelial growth of 10 fungi at 400ppm(Table7). 
The oil its MIC(400ppm) was able to inhibit the growth of all 10 discs(each of $5 \mathrm{~mm}$ diam) as well as growth of single mycelia discs of $11 \mathrm{~mm}$ diam, the maximum considered in this study. Thus fungitoxic potential of oil appeared to be retained heavy inoculums density. The highest temp(100C), autoclaving and storage upto 180 days,did not affect the toxicity of the oil against the test fungi and insect(Table 8).

\section{Preservation of sissoo seeds by Putranjiva seed kernel oil and fumigants during storage}

As evident from control sets in Table9, the sissoo seeds were associated with 15 fungal speciesviz.Alternaria

alternata,Aspergilluscandidus,A.flavus,A.niger,A.phoenicis,A.tamarii,A.terreus,A.sydowi,Fusarium moniliforme,F.oxysporum,F.solani,P.glabrum,Rhizopus nigricans,Trichoderma viride,Trichothecium roseum in both containers.

Bruchus pisorum was present in gunny bags but absent in sealed metal containers.

Sissoo treated with Putranjiva seed kernel oil were not associated with fungi or insects in either container.Phosphine was ineffective in control of the fungal species or Bruchus pisorum at an 80mg dose in both containers.At $120 \mathrm{mg}$, it was effective.Ethylene dibromide at 0.25 and $0.38 \mathrm{ml}$ was ineffective.

With respect to germination capacity,the oil treated seeds showed 80-90\%,phosphine $70-75 \%$ and ethylene dibromide55-65\%germination. The seeds of control set , however exhibited only 45-50\% seed germination(Table 10). The seed kernel oil had no adverse effect on seed germination,seedling growth and general health of sissoo plants when compared with control and synthetic fumigants.

\section{Discussion}

Several other fungal species were isolated by different workers from shisham seeds viz.,Aspergillus, Penicillium,Rhizopus,Alternaria,Fusarium,Chaetomium,Drechslera and Curvularia(Richardson,1990);F.solani and F.pallidoroseum(Ahmad and Bhutta,1993);Alternaria,Aspergillus and Fusarium(Manadhar et al.,2000);A.niger,A.flavus,A.terreus, Alternaria alternate, Chaetomiumsp,Drechslera australiensis,Fusarium pallidoroseum,F.solani,Fusarium sp.,Penicillium spp.,Rhizopus and Geotrichum sp.,(Khan et al.,2001);Rhizoctonia solani,Fusarium solani,F.oxysporum,F.moniliforme,Aspergillus niger,Alternaria alternata and Helminthosporium oryzae(Mustafa et al.,2004) and Fusarium solani,F.moniliforme,F.equiseti,F.oxysporum,F.semitectum, Rhizoctonia solani,Alternaria alternate, Curvularia lunata,Aspergillus niger and Penicillium sp(Rajput et al.,2010)but in present investigation 15 fungal species viz., Alternaria alternata,Aspergillus

candidus,A,flavus,A.niger,A.phoenicis,A.tamarii,A.terreus,A.sydowi,Fusarium

moniliforme,F.oxysporum,F.solani,P.glabrum,Rhizopus nigricans,Trichoderma viride,Trichothecium roseum were isolated.The variation in fungal species may be due to different climatic conditions, isolation periods and different storage containers.

Rajak et al(1992) studied post harvest mycoflora of some forest trees of Madhya Pradesh and found blotter method to be the best as it yielded maximum number of fungi in comparison to agar plate method.Similarily in present investigation blotter method yielded 15 fungi and agar plate method yielded 12 fungi.

The review of literature reveals that seed germination has been affected by fungal infections and caused mortality in shisham.Vigayan and Rehill(1990) and Pathan et al(2007) reported that Aspergillus flavus,A.niger,F.oxysporum has inhibitory effect on seed germination of shisham seeds.Rajput et al (2010) recorded 50\%germination and $93.3 \%$ mortality when infested with F.solani.In present investigation A.niger,F.solani and insect-Bruchus pisorum caused significant reduction in germination and mortality of shisham seeds.

Saxena et al(1983)reported MIC of Putranjiva leaf oil 500ppm against Helminthosporium oryzae while in present investigation the MIC of seed kernel oil was found to be 400ppm against both Aspergillus niger and Fusarium solani.Such small variations in the MIC of oil may be due to different techniques as well as test organisms used.The previous literature revealed that there is a marked variation in the MIC of different plant oils against Aspergillus niger-thus Ocimum adscendens Willd 200ppm(Asthana and Singh,1981),Cymbopogon flexuosus(Steud.)Wats 400ppm(Dixit,1991),Syzygium aromaticum(L.)Merrill and Perry 200ppm(Khan,1993),Cedrus deodara(Roxb.ex Lambert)G.Don 1000ppm and Trachyspermum ammi(L.)Sprague 500ppm(Singh and Tripathi,1999). The variation in the MIC of different plant oils may be due to the presence of different chemical constituents.

According to Wellman(1967) a fungicide must retain its fungitoxicity at the extreme of temperatures. The fungitoxicity of the seed kernel oil of Putranjiva was found to be thermostable upto 100C like Ageratum conyzoides(Dixit et al.,1995) and Nardostachys jatamansi(Mishra et al.,1995).The seed kernel oil retained its fungitoxicity on autoclaving(15lbs/square inch pressure).This quality of oil will facilitate the isolation of their constituents in active state. 
A fungicide should be able to retain its activity during long period of its storage(Wellman,1967).The fungitoxic factor in the oil of Adenocalyma allicea was lost within $21 \mathrm{~d}$ of storage(Chaturvedi,1979) while persisted for long period in the oil of Ageratum conyzoides(Dixit et al.,1995),Trachyspermum ammi(Singh and Tripathi,1999). The fungal toxicity was not affected by storage upto 180 days during present investigation.So this show that the seed kernel oil can be safely stored at any ambient temperature for long periods without loss in toxicity.

\section{Conclusion}

Thus,Putranjiva seed kernel oil shows potential as a potent fumigant preservative for the management of post harvest infestation of seeds of sissoo on the basis of its strong fungal toxicity at low MIC,insect repellency and long shelf life.

\section{Acknowledgement}

Author is thankful to Head, Department of Botany for providing Laboratory facilities.

\section{References}

[1]. Ahmad,I and Bhutta,A,R(1993)Fungi associated with land scape tree seed in Islamabad,Pakistan.Pakistan J.Phytopathol.,5;126-129.

[2]. Asthana,A and Singh,A.K(1981)Fungitoxic properties of essential oil of Ocimum adscendens.Journal of Indian Botanical SocietySupplement , 60; 13

[3]. Bocher,O.E(1938)Antibiotics.In;Modern methods of plant analysis.Eds.Peach K and Tracey M.V(ed.).Modern methods of plant analysis vol iii,651,Springer-Verlag,Berlin.

[4]. Booth,C(1971)The genus Fusarium.Commonwealth Mycological Institute,Kew,Surrey,England ,237pp.

[5]. Chaturvedi,R(1979)Evaluation of higher plants for their fungitoxicity against Helminthosporium oryzae.Ph.D Thesis Gorakhpur Uniersity,Gorakhpur,India.

[6]. Collins, P.J., Daglish, G.J., Pavic, H., Lambkin, T.M., Kapittke, R., 2002.Combating strong resistance to phosphine in stored grain pests in Australia. In: Wright, E.J., Banks, H.J., Highley, E. (Eds.), Stored Grain in Australia 2000. Proceedings of the Australian Postharvest Technical Conference, Adelaide, 1-4 August 2000. CSIRO StoredGrain ResearchLaboratory, Canberra, Australia, pp. $109-112$.

[7]. De Tempe(1962)Comparison of methods of seed health testing.Proc.Int.Seed Test Assoc.,27;819-828.

[8]. De Tempe,J(1953)The blotter method of seed health testing.Proc,Int.Seed test Assocn.,28;133-151.

[9]. Dixit,V(1991)Evaluation of volatile inhibitors from higher plants against storage fungi of Allium cepa.PhD thesis Gorakhpur University, Gorakhpur,India.

[10]. Dixit S.N.,Tripathi,N.N and Tripathi,S.C(1978)Fungitoxicity of some seed extracts .Nat.Acad.Sci.Letters 1;287-288.

[11]. Dixit,S.N.,Chandra,H.,Tiwari,R and Dixit,V(1995)Development of botanical fungicide against blue mould of mandarins.J.Stored Prod.Res.,31(2);165-172

[12]. Ellis,M.B(1971)Dematiaceous hyphomycetes.Commonwealth Mycological Institue,Kew,Surrey,England,608pp.

[13]. Ellis,M.B(1976)More dematiaceous hyphomycetes.CommonwealthMycological Institute,Kew.Surrey,England

[14]. Gillman J.C(1967) A manual of soil fungi.Oxford and JBH publishing co. Calcutta.India.

[15]. Grover R.K and Moore J.D(1962)Toximetric studies of fungicides against brown rot organism,Sclerotinia fructicola and S.laxa.Phytopath 52;876-880.

[16]. International Seed Testing Association(1985)International rules for seed testing.Seed Science and Technol, 31;299-366

[17]. Khan,S.A(1993)Control of fungal and insect deterioration of blackgram during storage by some higher plants. PhD thesis Gorakhpur University, Gorakhpur,India

[18]. Khan,H.S,Idrrees,M.,Mohmadd,F.Mahmood,A and Zaidi,S.H(2004)Incidence of sisham decline and invitro response of isolated fungus species to various fungicides.International Journal of Agriculture and Biology,6(4);611-614.

[19]. Khan,S.M.,Shakir,A.S,Tabssum,M.A and Rehman,A(2001)Isolation and identification of different fungi from disesed shisham tree.Proc of 3rdNat.Conf.of Plant Pathol,Oct 1-3,NARC,Islamabad,pp.44-46.

[20]. Kumar,N and Tripathi,N.N(2004)Repellent property of volatile oil isolated from Putranjiva roxburghii against Trogoderma granarium associated with stored groundnut seeds.Proc.Nat.Acad.Sci India 74B(11);179-187.

[21]. Langenau,E.E(1948)The examination and analysis of essential oils;synthetics and isolates.In;Guenther,E(Ed.)The essential oils Vol,1.Krieger Publishing Co.,Hutington,New York pp 227-348.

[22]. Manadhar,G. Shresta,S.K,Appanah,S,Allard,G and Amatya,S.M(2000)Fungi associated with dieback of sissoo.Proc.,of Intl,Seminar,Nepal,18;27-29.

[23]. MBTOC, (2002) Report of the Methyl Bromide Technical Options Committee (MBTOC) 2002 Assessment. UNEP, Nairobi, Kenya.

[24]. Mishra D.,Chaturvedi,R.V and Tripathi, S.C(1995)The fungitoxic effect of the essential oil of the herb Nardostachys jatamansi D.C. Tropical Agri 72(1);48-52.

[25]. Muskett A.F(1948)Technique for the examination of seeds for the presence of seed borne fungi.Trans.Br.Mycol,30;74-83.

[26]. Mustafa,A.,Khan S.M and Rehman ,A(2004)Fungi associated with shisham(Dalbergia sissoo Roxb.) and their control.Pak,J.Phytopathol,16;73-75.

[27]. Neergaard P(1977)Seed pathology vol1and2.Mavmillan press London.

[28]. Ormancy,Y.,Sissali,S and Coutiere,P(2001)Formulation of essential oils in functional perfumery.Perfumes Cosmetiques, Actualities, 157;30-40.

[29]. Pandey, D.K ,Chandra,H and Tripathi,N.N(1982)Volatile fungitoxicity of some higher plants with special reference to that of Callistemon lanceolatus D.C.Phytopath Z 105; $175-182$

[30]. Pathan,M.A,Rajput,N.A,Jiskani,M.M and Wagan K.H(2007)Studies on intensity of shisham dieback in Sindh and impact of seed borne fungi on seed germination.Pak.J.Agric.Agril Eng., Vet.Sci .23;12-17.

[31]. Rajak, C.K.,Rachana,A,Pandey,A,K(1992)Post harvest mycoflora and its impact on seed quality of some forest trees of Madhya Pradesh.J.Indian bot Soc.,71;107-108. 
[32]. Rajendran, S( 2002) Postharvest pest losses. In: Pimentel, D. (Ed.),Encyclopedia of Pest Management. Marcel Dekker, Inc., New York,pp. 654-656

[33]. Rajput,N.A.,Pathan,M.A,Rajput,A.Q,Jiskani,M.M,Lodhi,A.M,Rajput,S.A and Khaskhali,M.I(2010)Isolation of fungi associated with shisham trees and their effect on seed germination and seedling mortality.Pak.J.Bot.,42(1);369-374.

[34]. Raper,K.B and Fennell,D.I(1965)The genus Aspergillus.The Williams and Wilkins Company,Baltimore.686pp.

[35]. Raper,K.B and Thom,C(1949)A Manual of the Penicillia. Boulliere, Tindall and Cox.London,875pp.

[36]. Richardson,M.J(1990)An noted list of seed borne diseases $4^{\text {th }}$ ed ISTA,Zurich.

[37]. Sah,S.P.,Sharma,C.Kand Sehested,F(2003)Possible role of the soil in the sissoo forest decline in Nepal Terai.Plant Soil Environ,49;378-385.

[38]. Sawamura,M(2000)Aroma and functional properties of Japanese yuzu(Citrus junos Tanaka) essential oil.Aroma Research 1;14-19.

[39]. Singh,J and Tripathi,N.N(1999)Inhibition of storage fungi of black gram(Vigna mungo L) by some essential oils.Flavour Fragrance J. 14;1-4.

[40]. Taylor, R.W.D., 1989. Phosphine - a major fumigant at risk. International Pest Control 31, 10-14.

[41]. Tripathi N.N and Narendra Kumar(2007)Putranjiva roxburghii oil-A potential herbal preservative for peanuts during storage.Journal of stored Products Research,43;435-442.

[42]. Vigayan,A.K and Rehill,P.S(1990)Effect of culture filterates of of some seed borne fungi of Dalbergia sissoo Roxb.,on seed germination and seedling growth.Indian Forester,116;559-563.

[43]. Wellman,R.H(1967)Commercial development of fungicides.In;Plant pathology Problem and Progress Eds Holtan et al.,19081958.Indian University Press, Allahabad, India.

Table1.Occurrence of different fungi on the seeds of Dalbergia sissoo Roxb after 6 months of storage

\begin{tabular}{|l|l|l|l|l|}
\hline \multirow{2}{*}{ Fungi recorded } & Moist blotter method & \multicolumn{2}{l|}{ Czapeks dox agar method } \\
\cline { 2 - 5 } & US & SS & US & SS \\
\hline Alternaria alternate(Fr.)Keissler & 2.4 & 1.2 & 3.2 & - \\
\hline Aspergillus candidus Pers ex. & 2.1 & - & 3.3 & - \\
\hline A.flavus Link & 8.1 & 3.9 & 19.9 & 6.6 \\
\hline A.niger van Tieghem & 3.7 & 2.5 & 14.1 & 3.5 \\
\hline A.phoenicis Link & 1.2 & - & - & - \\
\hline A.tamarii Kita & 1.3 & - & 3.2 & - \\
\hline A.terreus Thom & 1.3 & - & - & - \\
\hline $\begin{array}{l}\text { A.sydowi } \text { Bainier and Sartory) } \\
\text { Thom and Church }\end{array}$ & 2.4 & 1.0 & 5.0 & 1.0 \\
\hline Fusarium moniliforme Sheldon & 8.1 & & & - \\
\hline F.oxysporum von Schlechtendal & 6.3 & 1.2 & 3.0 & 3.1 \\
\hline F.solani (Mart.)Sacc. & 5.4 & 1.4 & 6.3 & 3.6 \\
\hline $\begin{array}{l}\text { Penicillium glabrum } \text { (Wehmer) } \\
\text { Westling }\end{array}$ & 4.1 & 2.5 & 3.2 & - \\
\hline Rhizopus nigricans Ehr. & 2.3 & - & 11.2 & - \\
\hline Trichoderma viride Pers.ex.Fr. & 2.1 & - & - & - \\
\hline $\begin{array}{l}\text { Trichothecium roseum(Persoon) } \\
\text { Link ex }\end{array}$ & 1.2 & - & 1.3 & - \\
\hline
\end{tabular}

\section{Insect-Bruchus pisorum(Linnaeus)}

Table 2. Effect of culture filterate of fungi and insect-Bruchus pisorum on seed germination and seedling mortality of sissoo

\begin{tabular}{|l|l|l|}
\hline Fungal species & Percent germination & Percent mortality \\
\hline Alternaria alternata & 65.5 & 34.5 \\
\hline Aspergillus candidus & 65.6 & 34.4 \\
\hline A.flavus & 61.4 & 38.6 \\
\hline A.niger & 6.0 & 94.0 \\
\hline A.phoenicis & 58.6 & 41.4 \\
\hline A.tamarii & 40.2 & 59.8 \\
\hline A.terreus & 40.6 & 59.4 \\
\hline A.sydowi & 89.4 & 10.6 \\
\hline Fusarium moniliforme & 49.5 & 50.5 \\
\hline F.oxysporum & 35.4 & 64.6 \\
\hline F.solani & 24.2 & 75.8 \\
\hline P.glabrum & 65.9 & 34.1 \\
\hline Rhizopus nigricans & 66.4 & 33.6 \\
\hline Trichoderma viride & 85.3 & 14.7 \\
\hline Trichothecium roseum & 67.4 & 32.6 \\
\hline Sterilized distilled water(control) & 84.3 & 15.7 \\
Insect-Bruchus pisorum & $\mathbf{2 0 . 0}$ & $\mathbf{8 0 . 0}$ \\
\hline
\end{tabular}


Table 3.Evaluation of essential oils of higher plants against Aspergillus niger and F.solani

\begin{tabular}{|c|c|c|c|}
\hline \multirow[b]{2}{*}{ Plant species } & \multicolumn{3}{|c|}{ Per cent inhibition of mycelia growth of test fungi at 500ppm } \\
\hline & Family & Aspergillus niger & Fusarium solani \\
\hline Aegle marmelos(L.)Corea & Rutaceae & 47.3 & 52.1 \\
\hline Ageratum conyzoides $\mathrm{L}$. & Asteraceae & 76.5 & 64.2 \\
\hline A. houstonianum & Asteraceae & 82.5 & 80.5 \\
\hline Anetum graveolens $L$. & Umbelliferae & 39.0 & 33.0 \\
\hline Anisomeles ovate R.Br. & Lamiaceae & 64.3 & 60.3 \\
\hline Artabotrys hexpetalous(Lamm)Merr. & Annonaceae & 53.2 & 46.7 \\
\hline Azadirachta indica A. Juss. & Meliaceae & 43.1 & 38.7 \\
\hline Caesulia oxillaris Roxb. & Asteraceae & 49.1 & 47.1 \\
\hline Callestemon lanceolatus DC & Myrtaceae & 38.3 & 48.2 \\
\hline Cannabis sativa $\mathrm{L}$. & Cannabinaceae & 12.0 & 9.5 \\
\hline Cinnamomum tamla Nees and Bbrem & Lauraceae & 39.0 & 23.0 \\
\hline Citrus aurantifolia Christm & Rutaceae & 38.2 & 29.3 \\
\hline C.medica var limonia(L.) & Rutaceae & 47.9 & 59.3 \\
\hline Eucalyptus citriodora Hook & Myrtaceae & 49.1 & 35.8 \\
\hline E.globulus(l.) Herit & Myrtaceae & 60.0 & 34.9 \\
\hline Eupatorium capillifolum (L.) & Asteraceae & 40.0 & 30.9 \\
\hline Feronia elephantum Correa & Rutaceae & 49.7 & 60.3 \\
\hline F.limonia(L.) Swingle & Rutaceae & 50.8 & 65.4 \\
\hline Hyptis suaveolens(L.) Poit & Lamiaceae & 47.2 & 27.4 \\
\hline Lantana camera $\mathrm{L}$. & Verbenaceae & 58.3 & 39.1 \\
\hline L.indica Roxb. & Verbenaceae & 55.7 & 40.0 \\
\hline Mentha arvensis $\mathrm{L}$. & Lamiaceae & 53.9 & 38.6 \\
\hline M.piperata $\mathrm{L}$. & Lamiaceae & 63.3 & 50.3 \\
\hline M.spicata L. & Lamiaceae & 60.3 & 48.2 \\
\hline Murraya koenighii(L.)Spreng & Rutaceae & 25.8 & 40.1 \\
\hline Ocimum adscendens Willd & Lamiaceae & 53.0 & 52.4 \\
\hline O.basilicum $\mathrm{L}$. & Lamiaceae & 40.1 & 50.1 \\
\hline O.canum Sims & Lamiaceae & 50.1 & 75.0 \\
\hline O.sanctum L. & Lamiaceae & 49.1 & 52.3 \\
\hline Putranjiva roxburghii Wall & Euphorbiaceae & $100 *$ & $100 *$ \\
\hline Tagetes erecta L. & Asteraceae & 44.0 & 30.7 \\
\hline Thuja occidentalis L. & Cuppressaceae & 24.0 & 46.3 \\
\hline
\end{tabular}

Table 4.Insect repellent activity of essential oils of some plants

\begin{tabular}{|c|c|c|c|c|}
\hline \multirow[t]{2}{*}{ Plant species } & \multirow[t]{2}{*}{ Family } & \multicolumn{3}{|c|}{ \%repellency against Bruchus pisorum at following amounts of oil(ml) } \\
\hline & & 0.005 & 0.01 & 0.02 \\
\hline Aegle marmelos(L.)Corea & Rutaceae & 25 & 35 & 40 \\
\hline Ageratum conyzoides $\mathrm{L}$. & Asteraceae & 30 & 40 & 50 \\
\hline B. houstonianum & Asteraceae & 35 & 60 & 70 \\
\hline Anetum graveolens $L$. & Umbelliferae & 40 & 60 & 75 \\
\hline Anisomeles ovate R.Br. & Lamiaceae & 30 & 55 & 65 \\
\hline $\begin{array}{l}\text { Artabotrys } \\
\text { hexpetalous(Lamm)Merr. }\end{array}$ & Annonaceae & 35 & 40 & 50 \\
\hline Azadirachta indica A. Juss. & Meliaceae & 35 & 60 & 70 \\
\hline Caesulia oxillaris Roxb. & Asteraceae & 40 & 55 & 65 \\
\hline Callestemon lanceolatus DC & Myrtaceae & 30 & 40 & 50 \\
\hline Cannabis sativa $\mathrm{L}$. & Cannabinaceae & 15 & 20 & 30 \\
\hline $\begin{array}{l}\text { Cinnamomum tamla Nees and } \\
\text { Bbrem }\end{array}$ & Lauraceae & 30 & 50 & 60 \\
\hline Citrus aurantifolia Christm & Rutaceae & 30 & 40 & 50 \\
\hline C.medica var limonia $(\mathrm{L})$. & Rutaceae & 30 & 50 & 60 \\
\hline Eucalyptus citriodora Hook & Myrtaceae & 40 & 50 & 60 \\
\hline E.globulus(l.) Herit & Myrtaceae & 45 & 55 & 65 \\
\hline Eupatorium capillifolum (L.) & Asteraceae & 30 & 40 & 50 \\
\hline Feronia elephantum Correa & Rutaceae & 35 & 60 & 70 \\
\hline F.limonia(L.) Swingle & Rutaceae & 40 & 50 & 60 \\
\hline Hyptis suaveolens(L.) Poit & Lamiaceae & 30 & 45 & 60 \\
\hline Lantana camera $\mathrm{L}$. & Verbenaceae & 25 & 35 & 45 \\
\hline L.indica Roxb. & Verbenaceae & 30 & 40 & 50 \\
\hline Mentha arvensis L. & Lamiaceae & 20 & 35 & 45 \\
\hline M.piperata $\mathrm{L}$. & Lamiaceae & 25 & 35 & 50 \\
\hline M.spicata L. & Lamiaceae & 25 & 30 & 50 \\
\hline Murraya koenighii(L.)Spreng & Rutaceae & 10 & 20 & 30 \\
\hline Ocimum adscendens Willd & Lamiaceae & 30 & 40 & 50 \\
\hline O.basilicum L. & Lamiaceae & 30 & 35 & 45 \\
\hline O.canum Sims & Lamiaceae & 30 & 45 & 60 \\
\hline O.sanctum $\mathrm{L}$. & Lamiaceae & 35 & 55 & 65 \\
\hline
\end{tabular}


Fumigant Potential of seed kernel oil of Putranjiva roxburghii Wall against storage pests of seeds of

\begin{tabular}{|l|l|l|l|l|}
\hline Putranjiva roxburghii Wall & Euphorbiaceae & 60 & 75 & $100^{*}$ \\
\hline Tagetes erecta L. & Asteraceae & 40 & 70 & 80 \\
\hline Thuja occidentalis L. & Cuppressaceae & 35 & 45 & 50 \\
\hline
\end{tabular}

Table 5.Physicochemical properties of seed kernel oil from Putranjiva roxburghii

\begin{tabular}{|l|l|}
\hline Parameters & Values \\
\hline Specific gravity & 0.933 \\
\hline Specific rotation & +10 \\
\hline Refractive index & 1.405 \\
\hline Acid value & 3.55 \\
\hline Saponification number & 154.6 \\
\hline Ester number & 151.05 \\
\hline Phenolic content & Nil \\
\hline Solubility & $\begin{array}{l}\text { Completely miscible } \\
\text { with petroleum ether } \\
\text { acetone and 90\%ethanol } \\
\text { in 1;1ratio but insoluble } \\
\text { in water }\end{array}$ \\
\hline
\end{tabular}

Table 6. MIC of the seed kernel essential oil of Putranjiva roxburghii

\begin{tabular}{|c|c|c|}
\hline Dose of oil in ppm & Aspergillus niger & Fusarium solani \\
\hline 200 & 30 & 40 \\
\hline 300 & 70 & 80 \\
\hline 400 & 100 & 100 \\
\hline 500 & $100 *$ & $100^{*}$ \\
\hline 600 & 100 & 100 \\
\hline
\end{tabular}

*Fungicidal

Table 7.Fungitoxic spectrum of seed kernel oil of Putranjiva roxburghii at sub lethal, lethal and hyperlethal doses

\begin{tabular}{|l|l|l|l|l|}
\hline \multirow{2}{*}{ Fungal species } & \multicolumn{4}{|l|}{ Per cent inhibition of mycelial growth of isolated fungi } \\
\cline { 2 - 5 } & $\begin{array}{l}\text { Sublethal } \\
200 \mathrm{ppm}\end{array}$ & $\begin{array}{l}\text { Lethal } \\
400 \mathrm{ppm}\end{array}$ & $\begin{array}{l}\text { Hyperlethal } \\
600 \mathrm{ppm}\end{array}$ & $\begin{array}{l}\text { Hyperlethal } \\
800 \mathrm{ppm}\end{array}$ \\
\hline Alternaria alternata & 45.6 & 80.0 & 100.0 & 100.0 \\
\hline Aspergillus candidus & 49.6 & 89.0 & 100.0 & 100.0 \\
\hline A.flavus & 50.0 & 100.0 & 100.0 & 100.0 \\
\hline A.niger & 30.0 & 100.0 & 100.0 & 100.0 \\
\hline A.phoenicis & 40.0 & 100.0 & 100.0 & 100.0 \\
\hline A.tamarii & 48.0 & 100.0 & 100.0 & 100.0 \\
\hline A.terreus & 59.0 & 100.0 & 100.0 & 100.0 \\
\hline A.sydowi & 55.6 & 100.0 & 100.0 & 100.0 \\
\hline Fusarium moniliforme & 40.0 & 100.0 & 100.0 & 100.0 \\
\hline F.oxysporum & 42.0 & 79.6 & 100.0 & 100.0 \\
\hline F.solani & 40.0 & 100.0 & 100.0 & 100.0 \\
\hline P.glabrum & 59.0 & 100.0 & 100.0 & 100.0 \\
\hline Rhizopus nigricans & 54.0 & 100.0 & 100.0 & 100.0 \\
\hline Trichoderma viride & 55.0 & 80.0 & 90.0 & 100.0 \\
\hline Trichothecium roseum & 65.9 & 95.0 & 100.0 & 100.0 \\
\hline
\end{tabular}

Table 8.Effect of physical factors on the fungitoxicity of seed kernel oil of Putranjiva roxburghii Wall

\begin{tabular}{|l|l|}
\hline Physical factors & $\begin{array}{l}\text { Per cent inhibition of mycelial } \\
\text { growth at its MIC }\end{array}$ \\
\hline Temperature $\left({ }^{\circ} \mathrm{C}\right)$ & \\
Time of treatment-60min & 100 \\
$40^{\circ} \mathrm{C}$ & 100 \\
$60^{\circ} \mathrm{C}$ & 100 \\
$80^{\circ} \mathrm{C}$ & 100 \\
$100^{\circ} \mathrm{C}$ & 100 \\
\hline Autoclaving & \\
$(1515 \mathrm{~s} / \mathrm{sq}$ inch pressure at $120 \mathrm{C})$ & \\
For 15 min & 100 \\
\hline Storage in days & 100 \\
15 & 100 \\
30 & 100 \\
45 & 100 \\
60 & 100 \\
75 & 100 \\
90 & \\
105 & \\
\hline
\end{tabular}


Fumigant Potential of seed kernel oil of Putranjiva roxburghii Wall against storage pests of seeds of

\begin{tabular}{|l|l|}
\hline 120 & 100 \\
135 & 100 \\
150 & 100 \\
165 & 100 \\
180 & 100 \\
\hline
\end{tabular}

Table 9. Mycoflora of 200g seed of sissoo treated with Putranjiva seed kernel oil,phosphine and ethylene dibromide after 6 months of storage in $250 \mathrm{ml}$ containers

\begin{tabular}{|c|c|c|c|c|c|c|c|c|c|c|c|c|c|c|c|c|c|c|c|c|c|c|c|c|c|c|c|c|}
\hline \multirow[t]{5}{*}{ Fungal species } & \multicolumn{4}{|c|}{ control } & \multicolumn{24}{|c|}{ treatment } \\
\hline & & & & & \multicolumn{8}{|c|}{ Putranjiva oil } & \multicolumn{8}{|c|}{ Phosphine(mg) } & \multicolumn{8}{|c|}{ Ethylene dibromide(ml) } \\
\hline & & & & & \multicolumn{4}{|c|}{0.25} & \multicolumn{4}{|c|}{0.38} & \multicolumn{4}{|c|}{80} & \multicolumn{4}{|c|}{120} & \multicolumn{4}{|c|}{0.25} & \multicolumn{4}{|c|}{0.38} \\
\hline & \multicolumn{2}{|c|}{$\mathrm{A}$} & \multicolumn{2}{|l|}{$\mathrm{B}$} & \multicolumn{2}{|c|}{$\mathrm{A}$} & \multicolumn{2}{|c|}{ B } & \multicolumn{2}{|c|}{ A } & \multicolumn{2}{|l|}{$\mathrm{B}$} & \multicolumn{2}{|l|}{$\mathrm{A}$} & \multicolumn{2}{|l|}{$\mathrm{B}$} & \multicolumn{2}{|l|}{$\mathrm{A}$} & \multicolumn{2}{|l|}{$\mathrm{B}$} & \multicolumn{2}{|l|}{ A } & \multicolumn{2}{|l|}{ B } & \multicolumn{2}{|l|}{$\mathrm{A}$} & B & \\
\hline & $\mathrm{G}$ & $\mathrm{T}$ & $\mathrm{G}$ & $\mathrm{T}$ & $\mathrm{G}$ & $\mathrm{T}$ & $\mathrm{G}$ & $\mathrm{T}$ & $\mathrm{G}$ & $\mathrm{T}$ & $\mathrm{G}$ & $\mathrm{T}$ & $\mathrm{G}$ & $\mathrm{T}$ & $\mathrm{G}$ & $\mathrm{T}$ & $\mathrm{G}$ & $\mathrm{T}$ & $\mathrm{G}$ & $\mathrm{T}$ & $\mathrm{G}$ & $\mathrm{T}$ & $\mathrm{G}$ & $\mathrm{T}$ & $\mathrm{G}$ & $\mathrm{T}$ & $\mathrm{G}$ & $\mathrm{T}$ \\
\hline Alternaria alternata & + & + & + & + & & 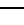 & & & 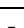 & 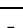 & 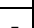 & 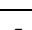 & 1 & + & + & + & + & 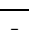 & + & 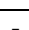 & $t$ & + & 4 & & + & 4 & & \\
\hline Aspergillus candidus & + & + & + & + & - & - & - & - & - & - & - & - & + & + & + & + & + & - & + & - & + & + & + & + & + & + & + & + \\
\hline A.flavus & + & + & + & + & - & - & - & - & - & - & - & - & + & + & + & + & + & - & + & + & + & + & + & + & + & + & + & + \\
\hline A.niger & + & + & + & + & - & - & - & - & - & - & - & - & + & + & + & + & + & - & + & - & + & + & + & + & + & + & + & + \\
\hline A.phoenicis & + & + & + & + & - & - & - & - & - & - & - & - & + & + & + & + & + & - & + & - & + & + & + & + & + & + & + & + \\
\hline A.tamarii & + & + & + & + & - & - & - & - & - & - & - & - & + & + & + & + & + & + & + & - & + & + & + & + & + & + & + & + \\
\hline A.terreus & + & + & + & + & - & - & - & - & - & - & - & - & + & + & + & + & + & - & + & - & + & + & + & + & + & + & + & + \\
\hline A.sydowi & + & + & + & + & - & - & - & - & - & - & - & - & + & + & + & + & + & - & + & - & + & + & + & + & + & + & + & + \\
\hline Fusarium moniliforme & + & + & + & + & - & - & - & - & - & - & - & - & + & + & + & + & + & - & + & - & + & + & + & + & + & + & + & + \\
\hline F.oxysporum & + & + & + & + & - & - & - & - & - & - & - & - & + & + & + & + & + & - & + & - & + & + & + & + & + & + & + & + \\
\hline F.solani & + & + & + & + & - & - & - & - & - & - & - & - & + & + & + & + & + & - & + & - & + & + & + & + & + & + & + & + \\
\hline P.glabrum & + & + & + & + & - & - & - & - & - & - & - & - & + & + & + & + & + & - & + & - & + & + & + & + & + & + & + & + \\
\hline Rhizopus nigricans & + & + & + & + & - & - & - & - & - & - & - & - & + & + & + & + & + & - & + & - & + & + & + & + & + & + & + & + \\
\hline Trichoderma viride & + & + & + & + & - & - & - & - & - & - & - & - & + & + & + & + & + & - & + & - & + & + & + & + & + & + & + & + \\
\hline Trichothecium roseum & + & + & + & + & - & - & - & - & - & - & - & - & + & + & + & + & + & - & + & - & + & + & + & + & + & + & + & + \\
\hline
\end{tabular}

Storage system;G-gunny bags; $\mathrm{T}$-tin containers

Detection method;A-agar plate technique;B-blotter tehnique

+ ;presence of fungi;-absence of fungi

Table 10. Germination of sissoo treated with Putranjiva seed kernel oil,phosphine and ethylene dibromide after 6 months storage of $200 \mathrm{~g}$ samples in $250 \mathrm{ml}$ containers

\begin{tabular}{|c|c|c|c|c|c|c|c|c|c|c|c|c|c|c|}
\hline \multirow[t]{4}{*}{ Period(days) } & \multicolumn{14}{|c|}{ Germination $\%$} \\
\hline & \multirow{2}{*}{\multicolumn{2}{|c|}{ control }} & \multicolumn{4}{|c|}{ Putranjiva oil } & \multicolumn{4}{|c|}{ Phosphine(mg) } & \multicolumn{4}{|c|}{ Ethylene dibromide(ml) } \\
\hline & & & \multicolumn{2}{|c|}{0.25} & \multicolumn{2}{|c|}{0.38} & \multicolumn{2}{|c|}{80} & \multicolumn{2}{|c|}{120} & \multicolumn{2}{|c|}{0.25} & \multicolumn{2}{|c|}{0.38} \\
\hline & G & $\mathrm{T}$ & $\mathrm{G}$ & $\mathrm{T}$ & $\mathrm{G}$ & $\mathrm{T}$ & $\mathrm{G}$ & $\mathrm{T}$ & $\mathrm{G}$ & $\mathrm{T}$ & $\mathrm{G}$ & $\mathrm{T}$ & $\mathrm{G}$ & $\mathrm{T}$ \\
\hline 10 & 15 & 15 & 15 & 15 & 15 & 15 & 15 & 15 & 15 & 15 & 15 & 15 & 20 & 15 \\
\hline 15 & 25 & 25 & 50 & 50 & 50 & 50 & 40 & 50 & 40 & 35 & 30 & 35 & 35 & 30 \\
\hline 20 & 45 & 45 & 75 & 85 & 75 & 80 & 65 & 70 & 65 & 65 & 60 & 60 & 50 & 35 \\
\hline 25 & 45 & 50 & 80 & 90 & 80 & 85 & 70 & 75 & 70 & 70 & 65 & 65 & 55 & 60 \\
\hline
\end{tabular}

G;Gunny bags

$\mathrm{T}$;Tin containers 